\title{
THE INFLUENCE OF E-LEARNING CHARACTERISTICS AND BASIC ICT COMPETENCIES TO ACTUAL USAGE OF E-LEARNING: A PATH DIAGRAM MODEL
}

\author{
I Made Suarta and I Ketut Suwintana
}

\author{
Bali State Polytechnic \\ Campus Bukit Jimbaran, Badung, Bali, 80364, Indonesia \\ Email: i_md_suarta@yahoo.co.id
}

\begin{abstract}
In this paper, the Technology Acceptance Model (TAM) is extent with two external stimulus namely e-learning characteristics and basic ICT (Information and Communication Technology) competencies. The purpose of this study are (1) finding relationship between e-learning characteristics and lecturers' basic ICT competencies with the perceived ease of use and perceived usefulness of e-learning; and (2) determining the effect of e-learning characteristics and lecturer basic ICT competencies to the actual usage of e-learning. Research subjects are Bali State Polytechnic lecturers who have attended the elearning training. In this study, to collect the data sample, a non-random sampling technique is adopted. The data is collected by self-administered questionnaires and is analyzed using structural equation modeling. Basic ICT competencies of the Bali State Polytechnic lecturers are good, but the level of actual usage of e-learning is very low. Basic ICT competence shows no significant effect on the perceived ease of use and perceived usefulness of e-learning. The actual usage of e-learning also has low implications. E-learning characteristics show a significant effect on perceived ease of use and perceived usefulness of e-learning, which implies the change attitude and behavior in the use of elearning. Characteristics of e-learning become a determinant factor in the adoption and use of elearning. The findings will help lecturer a better understanding to the mechanism of e-learning adoption. The study recommends for polytechnic institutions to make a systematic effort to provide lecturers with training on how to use e-learning system effectively. A further research to identify other factors that may influence lecturers' attitudes toward the adoption of e-learning system is demanded following this research.
\end{abstract}

Keywords: technology acceptance models, usefulness, ease of use, e-learning characteristics, ICT competency.

\begin{abstract}
Abstrak
Artikel ini membahas model penerimaan teknologi yang dikembangkan dengan menambahkan dua variabel yaitu karakteristik e-learning dan keterampilan dasar TIK. Tujuan penelitian ini adalah (1) menemukan hubungan antara karakteristik e-learning dan kompetensi dasar TIK dengan persepsi kemudahan dan kebermanfaatan e-learning; (2) mengetahui pengaruh karakteristik e-learning dan kompetensi dasar TIK terhadap penggunaan sesungguhnya dari e-learning. Sampel penelitian dipilih secara non-random dari staf pengajar Politeknik Negeri Bali yang pernah mengikuti pelatihan $e$ learning. Data dikumpulkan secara self-administered questionnaires dan dianalisis menggunakan model persamaan struktural. Kompetensi dasar TIK staf pengajar Politeknik Negeri Bali termasuk kategori baik, tetapi tingkat penggunaan e-learning sesungguhnya masih sangat rendah. Kompetensi dasar TIK berpengaruh tidak nyata terhadap persepsi kegunaan dan kemudahan menggunakan $e$ learning. Kondisi ini berimplikasi pada rendahnya penggunaan e-learning. Karakteristik e-learning berpengaruh nyata terhadap persepsi kegunaan dan kemudahaan menggunakan e-learning, hal ini berimplikasi pada perubahan sikap dan perilaku dalam menggunakan e-learning. Karakteristik $e$ learning menjadi faktor penentu dalam adopsi dan penggunaan e-learning. Temuan ini dapat membantu staf pengajar dalam memahami proses adopsi $e$-learning. Penelitian ini merekomendasikan pada institusi agar melakukan upaya-upaya sistematis melalui pelatihan penggunaan $e$-learning secara efektif. Disarankan untuk melakukan penelitian lanjutan untuk mengidentifikasi faktor-faktor lain yang berpengaruh terhadap minat dan sikap dosen dalam menggunakan e-learning.
\end{abstract}

Keywords: model penerimaan teknologi, kebermanfaatan, kemudahan menggunakan, karakteristikelearning, kompetensi TIK 


\section{Introduction}

E-learning systems have become popular tools for teaching and learning. E-learning is commonly referred to the intentional use of networked information and communication technology in teaching and learning [1]. A number of other terms are also used to describe this mode of teaching and learning. They include online learning, virtual learning, distributed learning, network and web based learning. The rapid development of information and communication technologies makes e-learning as a new paradigm for education. For some people, the e-learning is considered as a relatively new technology innovation. As a new product innovation, the use of e-learning is vulnerable to failure. The use of e-learning are less optimal, also there is a separate issue that needs attention. In the event of failure, the adoption of e-learning is not helpful to the learning process [2] [3].

The study of acceptance and use of information technology in various aspects has grown quite long. Technology acceptance model (TAM) from Davis has become a role model to assess acceptance and use of information technology [4]. TAM was developed by Davis adopted the Theory of Reasoned Action (TRA). In this model, Davis identifies the perceived ease of use and the perceived usefulness as the two key factors that determine the individual acceptance of the technology [4]. The actual use of technology is determined by the perception of usefulness and ease of use through the attitude towards the use of, rela-ting to intentions and behavior using the technology.

TAM model has been widely reviewed, replicated, and developed by other researchers [5][9]. Various variables such as intrinsic and extrinsic motivation, as well as external variables are added as a form of TAM development [10]. The results of these studies indicate TAM model is consistent and valid to explain the behavior of using technology.

Some variants of TAM are also developed specifically to assess the acceptance of e-learning [11]-[14]. E-learning Acceptance Model (ELAM) developed by Selim et al. shows that the characteristics of the instructors, support organizations, as well as the information technology infrastructure of the organizations have direct and signifycant impact on students acceptance of e-learning [11]. Research conducted by Mahdizadeh et al. aims to identify factors that can explain the use of e-learning by lecturers in higher education [12]. Research results show the ease of use and usefulness can be used to predict the actual use of e-learning by faculty.
Many studies deal with the identification of factors and their impact on a user's acceptance of e-learning. Several studies also have been conducted in order to find answers to the occurrence of failures in the adoption of e-learning, by investigate the perspective of the individual user of elearning. Studies of the determinants use of elearning shows the user individual factors play an important role in improving the effectiveness use of e-learning. A literature review conducted by King Yee et al. identifies the perceived ease of use and perceived usefulness of e-learning and attitudes use of e-learning becomes determinant factors actual usage of e-learning [15].

Lee et al. adds some external variables in the model TAM [13]. The external variables associated with innovation diffusion theory, which includes compatibility, complexity, relative advantage, observability, and trialability. Research results show that the compatibility have a signifycant effect on the perception of the usefulness and the intention to use e-learning. Complexity has a negative effect on the perceived ease of use and the intention to use e-learning. Relative advantage has a significant effect on all the variables of elearning acceptance. Observability has no signifycant effect on the perception of usefulness and the ease of use of e-learning. Meanwhile, trialability negatively affects the perception usefulness of elearning.

According to [16] the relative advantage, compatibility, trialability, and observability of an innovation as perceived by members of a social system, are positively related to rate of adoption. The complexity of an innovation is negatively related to the rate of adoption.

Other researchers also examine the perceived credibility [17], experience to the use of information technology and computer knowledge [18] as independent variables in the original TAM model. The result show experience to the use of information technology and computer knowledge have positive relationship to the behavioral intention to adopt e-learning system.

This study examines the determinants of acceptance and use of e-learning by faculty staff using the approach of innovation adoption theory combined with the technology acceptance model. In this model, the basic competencies of ICT lecturers and characteristics of e-learning is an external factor that becomes a stimulus in the acceptance and use of e-learning. This study aims to find a causal relationship between the basic competencies of ICT lecturers and characteristics of elearning with the perceived ease of use and the perceived usefulness of e-learning. In addition, this study also aims to provide a basic overview of the influence of ICT competence of lecturers and 
characteristics of e-learning to the acceptance and use of e-learning.

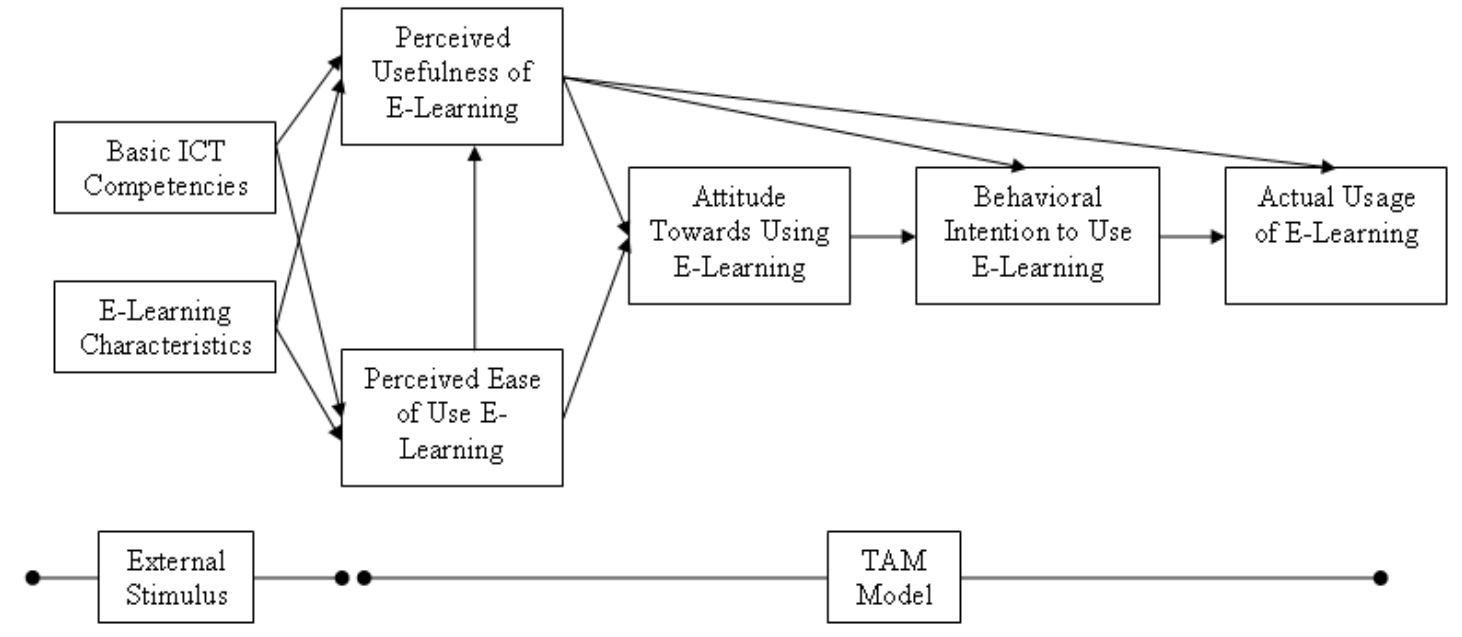

Fig.1. The research model

\section{Methodology}

\section{Research Framework}

The conceptual framework of this study adopts the use of ICT model developed by Usluel et al. [16], e-learning acceptance model developed by Lee et al. [13] and TAM were developed by Davis et al. [20]. The fundamental difference of this study lies in the basic ICT competence factor and characteristics of e-learning as an external stimulus. Fig. 1 shows the research model used in this study. In this model, the basic competencies of ICT and e-learning characteristics are external factors that determine the perceived ease of use and the perceived usefulness of e-learning.

TABLE 1

RESEARCH CONSTRUCTS AND MEASUREMENT

\begin{tabular}{|c|c|c|c|}
\hline Constructs & Items & Measure & Authors \\
\hline $\begin{array}{l}\text { E-Learning } \\
\text { Characteristics }\end{array}$ & $\begin{array}{l}\mathrm{CH} 1 \\
\mathrm{CH} 2 \\
\mathrm{CH} 3 \\
\mathrm{CH} 4 \\
\mathrm{CH} 5\end{array}$ & $\begin{array}{l}\text { E-learning have relative advantage compare to others } \\
\text { learning model. } \\
\text { E-learning compatible with vocational learning model. } \\
\text { It is easy for me to learn and use e-learning. } \\
\text { I had the opportunity to try out how I can make use of e- } \\
\text { learning in my profession. } \\
\text { I observe easily those others in use of e-learning. }\end{array}$ & $\begin{array}{l}\text { Developed by authors with } \\
\text { adapted from Usluel et al. } \\
{[16]}\end{array}$ \\
\hline $\begin{array}{l}\text { Perceived Ease of } \\
\text { Use E-Learning }\end{array}$ & $\begin{array}{l}\text { EU1 } \\
\text { EU2 } \\
\text { EU3 } \\
\text { EU4 }\end{array}$ & $\begin{array}{l}\text { I find e-learning platform easy to use. } \\
\text { I find it easy to get e-learning platform to do I want it to } \\
\text { do. } \\
\text { My interaction with e-learning platform was clear and } \\
\text { understandable. } \\
\text { I find e-learning platform flexible to interact with. }\end{array}$ & $\begin{array}{l}\text { Adapted from Davis [4]; } \\
\text { Davis et al. [20] }\end{array}$ \\
\hline $\begin{array}{l}\text { Perceived Usefulness } \\
\text { E-Learning }\end{array}$ & $\begin{array}{l}\text { PU1 } \\
\text { PU2 } \\
\text { PU3 } \\
\text { PU4 }\end{array}$ & $\begin{array}{l}\text { Using e-learning platform ameliorate the course } \\
\text { understandable. } \\
\text { Using e-learning platform enhanced my effectiveness in } \\
\text { the course. } \\
\text { Using e-learning platform enhanced my interaction with } \\
\text { the instructors. } \\
\text { Using e-learning platform makes it easier to learn. }\end{array}$ & $\begin{array}{l}\text { Adapted from Davis [4]; } \\
\text { Davis et al. [20] }\end{array}$ \\
\hline $\begin{array}{l}\text { Attitude Toward } \\
\text { Using E-Learning }\end{array}$ & $\begin{array}{l}\text { AT1 } \\
\text { AT2 } \\
\text { AT3 } \\
\text { AT4 }\end{array}$ & $\begin{array}{l}\text { Using the e-learning is a good idea } \\
\text { Using the e-learning is a wise idea } \\
\text { I like the idea of using the e-learning } \\
\text { Using the e-learning is pleasant }\end{array}$ & $\begin{array}{l}\text { Adapted from Davis et al. } \\
\text { [20]; Taylor \& Todd [21]. }\end{array}$ \\
\hline $\begin{array}{l}\text { Behavioral Intention } \\
\text { to Use E-Learning }\end{array}$ & $\begin{array}{l}\mathrm{BI} 1 \\
\mathrm{BI} 2 \\
\mathrm{BI} 3\end{array}$ & $\begin{array}{l}\text { Assuming e-learning availability in other courses, I will } \\
\text { use it } \\
\text { I intend to use frequently e-learning in the frame of other } \\
\text { courses } \\
\text { I intend to choose more courses using e-learning in the } \\
\text { next semesters }\end{array}$ & $\begin{array}{l}\text { Adapted from Davis et al. } \\
\text { [20], Taylor \& Todd [21]. }\end{array}$ \\
\hline
\end{tabular}




\section{Data Collection Procedure}

The research is conducted by survey method using a questionnaire as a data collection tool. Subjects are Bali State Polytechnic lecturers who have attended the training of e-learning. Thus, in this stu-dy, a non-random sampling technique is adopted to collect the sample data. The data are collected by self-administered questionnaires, in which res-pondents answer questions without the help of the data collector [19]. In this study, 130 question-naires are distributed. There are 113 question-naires that are filled in correctly, completely, and deserve further analysis. The response rate in this study was $86.9 \%$.

\section{Research Instruments}

The questionnaire used in this study consists of two parts. The first part contains the characteristics of the respondents, the basic ICT competencies, and the actual use of e-learning. The actual usage e-learning by faculty is measured using indicators: (1) the content of the e-learning that has been made, (2) the frequency of the use of elearning in learning, and (3) use of e-learning experience. The second part contains the characterristics of e-learning as well as the determinants of acceptance and use of e-learning. To ensure content validity of the scales, the items chosen for the constructs were adapted from previous research [16], [4], [20], and [21]. All items are measured using five-point Likert scale with anchors from "Strongly disagree" to "Strongly agree". TABLE 1 presents measure for each of the constructs. Validity and reliability of the instrument is tested using Pearson Product Moment correlation and Cronbach's Alpha (TABLE 5).

\section{Data Analysis}

Data are analyzed by descriptive statistics including means, standard deviation, frequency distribution; and structural equation models. Structural model illustrates the relationships that exist between latent variables, and the general shape of a linear relationship. The suitabilities of structural models are evaluated using multiple fit indices such as Chi-Square Statistic $\left(\Pi^{2}\right)$, Good-ness of Fit Index (GFI), Adjusted Goodness of Fit Index (AGFI), Non-normed Fit Index (NNFI), Comparative Fit Index (CFI), Root Mean Square Residual (RMSR), dan the Root Mean Square Error of Approximation (RMSEA) [22].

\section{Result and Disscussion}

\section{Characteristics Respondent}

A general description of the sample as shown in TABLE 2.
There is $72.6 \%$ (82 people) sample of males and $27.4 \%$ (31 people) are women. The largest population of respondents aged between 40-49 years, which is 64 people $(56.6 \%)$. Based on years of service, there are 42 people $(37.2 \%)$ with tenure more than 21 years, 26 people $(23 \%)$ with years of service $16-20$ years and six people $(5.3 \%)$ with tenure less than 5 years.

TABLE 2

CHARACTERISTICS RESPONDENT

\begin{tabular}{cccc}
\hline \multirow{2}{*}{ Profile } & \multicolumn{2}{c}{ Research Group } \\
\cline { 3 - 4 } & & $\begin{array}{c}\text { Number of } \\
\text { Respondent }\end{array}$ & Percentage \\
\hline \multirow{2}{*}{ Gender } & Male & 82 & 72.6 \\
& Female & 31 & 27.4 \\
\hline \multirow{3}{*}{ Age } & $<=29$ & 1 & 0.9 \\
& $30-39$ & 24 & 21.2 \\
& $40-49$ & 64 & 56.6 \\
Years of & $>=50$ & 24 & 21.2 \\
service & $11-15$ & 6 & 5.3 \\
& $16-20$ & 15 & 13.3 \\
& $>=21$ & 24 & 21.2 \\
& $<-10$ & 42 & 23.0 \\
\hline
\end{tabular}

\section{Basic ICT Competency}

Basic ICT competencies include word-processing applications, spreadsheet applications, database applications, presentation applications, multimedia applications, using search engine on the Internet, sending and receiving e-mail, etc. In general, lecturers at PNB have sufficiently good basic ICT competence. 65 people $(57.9 \%)$ are included in the category of competent and very competent while the rest four people $(3.4 \%)$ are included in the category of not competent. Most lecturers are competent in the field of word-processing application, spreadsheet application, presentation application, search engine application on the Internet, and e-mail applications while less competent in the field of database applications and multimedia applications as shown in TABLE 3.

\section{Actual Usage of E-Learning}

Actual use of e-learning is measured with the following indicators i.e. (1) The number of courses that has made e-learning materials; (2) The number of topics or sub-topics in a course that has made e-learning materials; (3) The frequency use of e-learning in the learning process in one semester; and (4) the experience in using elearning. The frequency distribution for each indicator of the actual usage of e-learning are presented in TABLE 4. 
TABLE 3

BASIC ICT COMPETENCY

\begin{tabular}{|c|c|c|c|c|c|c|c|c|c|c|}
\hline \multirow{2}{*}{ Basic ICT } & \multicolumn{2}{|c|}{ Not competent } & \multicolumn{2}{|c|}{ Less competent } & \multicolumn{2}{|c|}{ Fairly competent } & \multicolumn{2}{|c|}{ Competent } & \multicolumn{2}{|c|}{ Very competent } \\
\hline & freq & $\%$ & freq & $\%$ & freq & $\%$ & freq & $\%$ & freq & $\%$ \\
\hline $\begin{array}{l}\text { Wordprocessing } \\
\text { application }\end{array}$ & 0 & 0.0 & 3 & 2.7 & 26 & 23.0 & 70 & 61.9 & 14 & 12.4 \\
\hline $\begin{array}{l}\text { Spreadsheet } \\
\text { application }\end{array}$ & 5 & 4.4 & 10 & 8.8 & 26 & 23.0 & 59 & 52.2 & 13 & 11.5 \\
\hline Database application & 14 & 12.4 & 33 & 29.2 & 30 & 26.5 & 31 & 27.4 & 5 & 4.4 \\
\hline $\begin{array}{l}\text { Presentation } \\
\text { application }\end{array}$ & 0 & 0.0 & 4 & 3.5 & 29 & 25.7 & 60 & 53.1 & 20 & 17.7 \\
\hline $\begin{array}{l}\text { Multimedia } \\
\text { application }\end{array}$ & 4 & 3.5 & 23 & 20.4 & 39 & 34.5 & 38 & 33.6 & 9 & 8.0 \\
\hline $\begin{array}{l}\text { Search engine } \\
\text { application }\end{array}$ & 2 & 1.8 & 4 & 3.5 & 45 & 39.8 & 42 & 37.2 & 20 & 17.7 \\
\hline E-mail application & 2 & 1.8 & 2 & 1.8 & 32 & 28.3 & 50 & 44.2 & 27 & 23.9 \\
\hline Average & 4 & 3.4 & 11 & 10.0 & 32 & 28.7 & 50 & 44.2 & 15 & 13.7 \\
\hline
\end{tabular}

Among the lecturers who participated in this study, there are 110 people $(97.3 \%)$ who have developed the e-learning material for one or more courses and 3 people $(2.7 \%)$ who have not developed the e-learning materials. 96 people $(85.0 \%)$ have developed e-learning materials for more than four topics in one course. Just that, the frequency use of e-learning in one semester is still very low.

There are 77 lecturers $(68.1 \%)$ whose the using frequency is less than three times. This condition is also associated with the experience of lecturers in using e-learning, where 69 lecturers $(61.1 \%)$ do not have the experience and less experienced in the use of e-learning. Based on the results it can be stated that the actual use of e-learning by lecturers at PNB is very low.

\section{Descriptive Statistics, Validity and Reliability}

The summary of descriptive statistics (means and standard deviation), the validity and reliability of research instruments are presented in TABLE
5. The validity and reliability of the instrument was tested using Pearson Product Moment and Cronbach's Alpha. The validity of research instruments shows significant results i.e. at $\mathrm{p}<0.05$ and $\mathrm{p}<0.01$. A key finding is the extremely low value of complexity (CH3) which is about 0.216 and number of courses (AU1) which is about 0.424 , but still significant at level $\mathrm{p}<0.01$.

The majority of the constructs exceeded 0.6, exceptions the actual usage of e-learning produced values $(0.553)$ greater than 0.5 , thus considered acceptable.

\section{Analysis of the Structural Model}

The structural model is most useful in representing the interrelationships of variables between constructs. The results analysis in the form of path diagrams with an estimated standardized solution are as shown in Fig.2. Path diagram is a visual representation of a model and the complete set of relationships among the model's constructs. In

TABLE 4

DESCRIPTIVE StATISTICS ACTUAL USAGE OF E-LEARNING.

\begin{tabular}{|c|c|c|c|}
\hline \multicolumn{2}{|l|}{ E-Learning Usage } & \multirow{2}{*}{$\frac{\text { Frequency }}{3}$} & \multirow{2}{*}{$\begin{array}{ll}\% & \\
& 2.7\end{array}$} \\
\hline Number of courses has made e-learning materials & Nothing & & \\
\hline & 1 course & 100 & 88.5 \\
\hline & 2 courses & 9 & 9.0 \\
\hline & 3 courses & 1 & 0.9 \\
\hline & $>=4$ courses & 0 & 0.0 \\
\hline \multirow{5}{*}{$\begin{array}{l}\text { Number of topics or sub-topics in a course that has made e- } \\
\text { learning materials }\end{array}$} & Nothing & 3 & 2.7 \\
\hline & $1-3$ topics & 14 & 12.4 \\
\hline & $4-6$ topics & 28 & 24.8 \\
\hline & $7-9$ topics & 36 & 31.9 \\
\hline & $>=10$ topics & 32 & 28.3 \\
\hline \multirow[t]{5}{*}{ The frequency use of e-learning in one semester } & Less than 3 times & 77 & 68.1 \\
\hline & Between 4 - 6 times & 18 & 15.9 \\
\hline & Between $7-9$ times & 12 & 10.6 \\
\hline & Between $10-12$ times & 4 & 3.5 \\
\hline & More than 12 times & 2 & 1.8 \\
\hline \multirow[t]{5}{*}{ Using e-learning experience } & Not experienced & 16 & 14.2 \\
\hline & Less experienced & 53 & 46.9 \\
\hline & Fairly experienced & 38 & 33.6 \\
\hline & Experienced & 6 & 5.3 \\
\hline & Very experienced & 0 & 0.0 \\
\hline
\end{tabular}


TABLE 5

Summary of Descriptive Statistics, Product Moment AND Cronbach's AlPha

\begin{tabular}{|c|c|c|c|c|c|}
\hline Construct & Variable & Means & SD & $\begin{array}{l}\text { Product Moment } \\
\text { Coefficient }\end{array}$ & $\begin{array}{l}\text { Cronbach's } \\
\text { Alpha }\end{array}$ \\
\hline \multirow[t]{6}{*}{ E-Learning Characteristics } & & & & & 0.648 \\
\hline & $\mathrm{CH} 1$ & 3.916 & 0.566 & $0.735^{* *}$ & \\
\hline & $\mathrm{CH} 2$ & 3.531 & 0.695 & $0.794 * *$ & \\
\hline & $\mathrm{CH} 3$ & 3.007 & 0.747 & $0.216^{*}$ & \\
\hline & $\mathrm{CH} 4$ & 3.714 & 0.502 & $0.760 * *$ & \\
\hline & CH5 & 3.662 & 0.746 & $0.820 * *$ & \\
\hline \multirow[t]{5}{*}{ E-Learning Ease of Use } & & & & & 0.789 \\
\hline & EU1 & 3.407 & 0.809 & $0.790 * *$ & \\
\hline & EU2 & 3.319 & 0.771 & $0.833 * *$ & \\
\hline & EU3 & 3.743 & 0.788 & $0.737 * *$ & \\
\hline & EU4 & 3.611 & 0.761 & $0.773^{* *}$ & \\
\hline \multirow[t]{5}{*}{ E-Learning Usefulness } & & & & & 0.719 \\
\hline & PU1 & 3.841 & 0.702 & $0.713^{* *}$ & \\
\hline & PU2 & 4.009 & 0.648 & $0.696^{* *}$ & \\
\hline & PU3 & 3.761 & 0.759 & $0.806^{* *}$ & \\
\hline & PU4 & 3.982 & 0.641 & $0.729 * *$ & \\
\hline \multirow[t]{5}{*}{ Attitude Toward Using E-Learning } & & & & & 0.871 \\
\hline & AT1 & 4.150 & 0.616 & $0.872 * *$ & \\
\hline & AT2 & 3.920 & 0.781 & $0.843^{* *}$ & \\
\hline & AT3 & 3.735 & 0.707 & $0.881 * *$ & \\
\hline & AT4 & 3.841 & 0.727 & $0.818 * *$ & \\
\hline \multirow[t]{4}{*}{ Behavioral Intention to Use E-Learning } & & & & & 0.850 \\
\hline & BI1 & 4.062 & 0.672 & $0.858^{* *}$ & \\
\hline & BI2 & 4.044 & 0.660 & $0.915^{* *}$ & \\
\hline & $\mathrm{BI} 3$ & 3.850 & 0.847 & $0.877 * *$ & \\
\hline \multirow[t]{5}{*}{ Actual Usage of E-Learning } & & & & & 0.553 \\
\hline & AU1 & 2.071 & 0.371 & $0.424 * *$ & \\
\hline & AU2 & 3.699 & 1.109 & $0.706^{* *}$ & \\
\hline & AU3 & 1.549 & 0.945 & $0.754 * *$ & \\
\hline & AU4 & 2.301 & 0.778 & $0.721 * *$ & \\
\hline
\end{tabular}

**) significant level $\mathrm{p}<0.05$

*) significant level $\mathrm{p}<0.01$

this model, the basic ICT competencies and characteristics of e-learning is an independent construct that becomes predictor variable to the actual usage of e-learning.

TABEL 6

STATISTICS OF PATH ANALYSIS

\begin{tabular}{ccc}
\multicolumn{3}{c}{ STATISTICS OF PATH ANALYSIS } \\
\hline Path & Path Coefficient & T-value \\
\hline TIK $\rightarrow$ EU & -0.03 & -0.39 \\
TIK $\rightarrow$ PU & 0.09 & 1.25 \\
CH $\rightarrow$ EU & 0.52 & $8.81^{* *}$ \\
CH $\rightarrow$ PU & 0.64 & $5.08^{* *}$ \\
EU $\rightarrow$ PU & 0.8 & $3.23^{* *}$ \\
EU $\rightarrow$ AT & 0.30 & $3.58^{* *}$ \\
PU $\rightarrow$ AT & 0.50 & $5.08^{* *}$ \\
PU $\rightarrow$ BI & 0.24 & $2.74 * *$ \\
AT $\rightarrow$ BI & 0.57 & $5.58^{* *}$ \\
BI $\rightarrow$ AU & 0.24 & $2.51^{* *}$ \\
\hline
\end{tabular}

**) significant level $\mathrm{p}<0.05$

*) significant level $\mathrm{p}<0.01$

The reliability of instruments with Cronbach's Alpha, which values are in the range of
0.60 to 0.70 deem the lower limit of acceptability [22].

The causal relationship between latent variables are evaluated using the path coefficient values $(\gamma$ or $\beta$ ) and $t$-value. The relationship between two latent variables declares significant result if the $\mathrm{t}$-value is greater than or equal to 1.96. Path coefficient and t-value of relationships is as hypothesized in TABLE 6.

The analysis shows basic ICT competence has no significant effect on perceived ease of use and perceived usefulness of e-learning. Meanwhile, e-learning characteristics show a signifycant effect on perceived ease of use and perceived usefulness of e-learning.

The total effect of variable basic ICT competence and e-learning characteristics of the perceived ease of use, perceived usefulness, attitude toward using e-learning, behavioral intention to use e-learning, and the actual usage of e-learning

TABEL 7

STANDARDIZED TOTAL EFFECTS OF X ON Y

\begin{tabular}{lcc}
\hline & Basic ICT Competencies (TIK) & E-Learning Characteristics (CH) \\
\hline Perceived Usefulness (PU) & 0.00 & 0.70 \\
Perceived Ease of Use (EU) & 0.09 & 0.64 \\
Attitudes Towards Use (AT) & 0.03 & 0.54 \\
Behavior Intention to Use (BI) & 0.02 & 0.47 \\
Actual Usage E-Learning (AU) & 0.00 & 0.11 \\
\hline
\end{tabular}




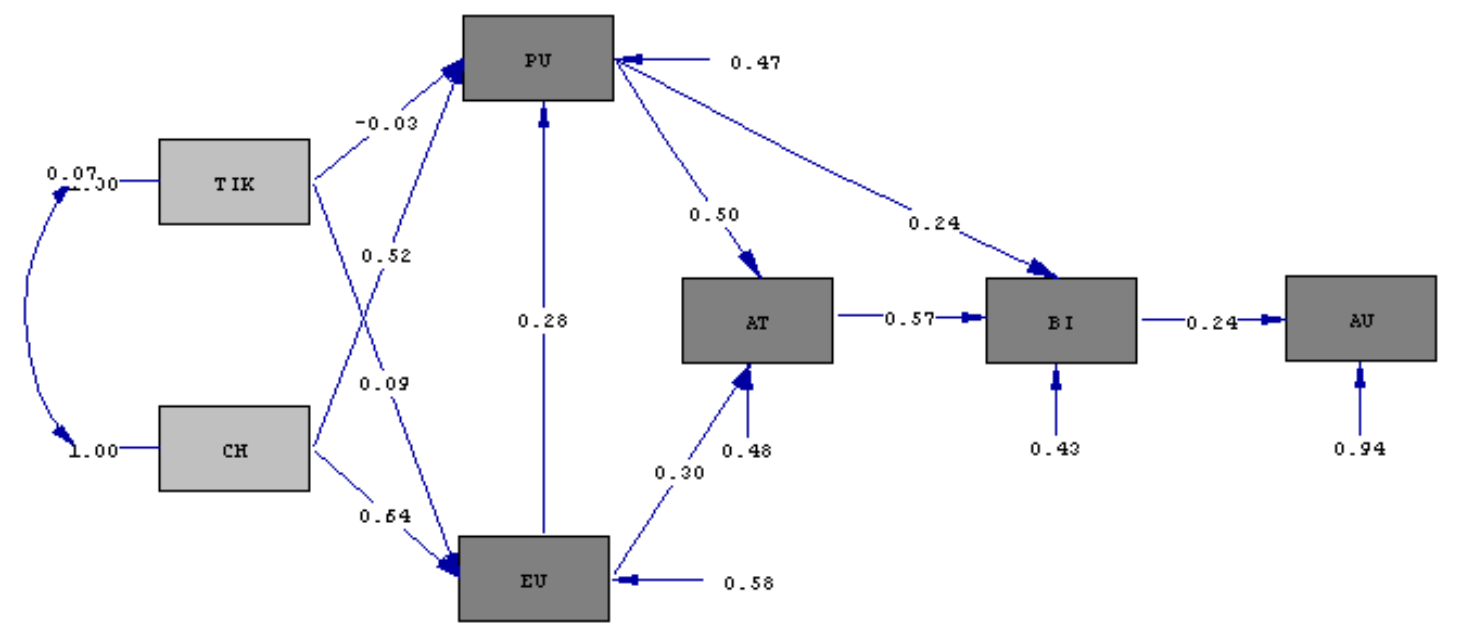

Fig.2. Path model with standardized solution. TIK = Basic ICT Competency; $\mathrm{CH}=$ E-Learning characteristics; PU $=$ Perceived Usefulness; EU = Perceived Ease of Use; AT = Attitudes Towards Use; BI = Behavior Intention to Use; AU = Actual Usage ELearning

are summarized in TABLE 7.

The model fit is evaluated using several criteria goodness of fit. Result analysis shows that the root mean square residual (RMSR) and goodness-of-fit index (GFI) have a good index. The observed value of RMSR is 0.0026 and fit with the cut-off value $(\leq 0.10)$, and value of GFI is 0.90 and fit with the cut-off value $(\geq 0.90)$. on the other hand, some other fit indices have a value below the specified cut-off value.

\section{Discussion}

The purpose of this study is to develop an acceptance model of e-learning by faculty who combine TAM with the basic ICT competencies and e-learning characteristics as external factors. Based on the research conceptual framework, this study explores the relationship between the Basic ICT competences and e-learning characteristics with variables of TAM. The study also identified the influence of the total basic ICT competencies and characteristics of e-learning to the actual usage of e-learning.

The result shows that the relationships in the model almost all have significant result except for the relationship between basic ICT competence with the perceived ease of use and perceived usefulness. These findings indicate the basic ICT competence has no effect on perceived ease of use and usefulness of e-learning. In general, the basic ICT competence of Bali State Polytechnic lecturers is fairly good but the usage level of elearning by lecturers is very low. The total effect of basic ICT competence on the actual usage of elearning is very low as shown in TABLE 7.
E-learning characteristics show a significant effect on perceived ease of use and perceived usefulness. If we observe further, the relationship between perceived ease of use with perceived usefulness show significant results. This finding is consistent with the results of previous studies [4] [11] [12] [13] where perceived ease of use and perceived usefulness has a very strong relationship. The analogy is that if e-learning is perceived easy to use, the e-learning will be usefully perceived. Results of this study indicate that the characterristics of the e-learning are determinant factors in establishing perceived ease of use and perceived usefulness of e-learning.

The next implication is in the attitude and behavior of using e-learning. The total effect of elearning characteristics on the actual usage of elearning reaches 0.11 . The results are consistent with the research conduct by [13] where e-learning characteristics have a significant effect on the actual usage of e-learning. In relation with the results of this study, e-learning content development needs to take into consideration with the characteristics of e-learning innovation.

This study also finds that perceived ease of use and perceived usefulness have a direct and significant effect on the attitude toward the use of e-learning. The perceived usefulness and the attitude toward the use of e-learning also have a direct and significant effect on the behavioral intention to use e-learning. If e-learning is usefully perceived, it will cause behavioral intention to use elearning. These results are consistent with research conducted by [5]. 
The evaluation of the goodness of fit index shows only RMSR and GFI is above the cut-off value. Based on this fit index, there is a good fit between the empirical data with the estimated model. However, some other fit indices have a value below the specified threshold. These results mean that the overall model is developed based on the theoretical studies have not supported by empirical data.

\section{Research Implications}

The main results show basic ICT competence not significant effect on the use of e-learning in polytechnics. This research provides several important implications for various stakeholders involved in building and promoting effective elearning systems in polytechnics. Polytechnics should promote and increase e-learning awareness and encourage the use of e-learning, both lecturers and students. Therefore, institutions should make a systematic effort to provide lecturers with training on how to use e-learning system effectively, and then the trained lecturers will influence their adoption attitude to their students.

\section{Conclusions and Recommendations}

The evaluation of e-learning content development conducted by lecturers at the Bali State Polytechnic is good enough. It is just the frequency in using the e-learning in learning process is still very low. This condition is consistent with the assumption that e-learning is considered as one of the products of relatively recent technological innovation. As a new product innovation, the usage level of e-learning by lecturers at the Bali State Polytechnic is very low.

The basic ICT competence shows no signifycant effect on the perceived ease of use and perceived usefulness of e-learning. In general, the basic ICT competence of Bali State Polytechnic lecturers are good but the usage level of e-learning is very low. Thus the total effect of the basic ICT competence and the actual usage of e-learning is very low.

E-learning characteristics show a significant association with the perceived ease of use and perceived usefulness of e-learning. Characteristics of e-learning into the determinant factors of adoption of e-learning, with a total effect of 0.11. Characteristics of e-learning will form a perception of ease of use and perceived usefulness of e-learning, which implies the change in attitude and behavior in using e-learning.

The study recommends that polytechnic institutions should make a systematic effort to provide lecturers with training on how to use e-learning system effectively. Further research should be carried out to identify other factors that may influence lecturers' attitudes toward the adoption of elearning system.

\section{References}

[1] Naidu, S. (2006). E-Learning: A Guide Book of Principles, Procedures and Practices. 2nd Revised Edition. New Delhi, India: Commonwealth Educational Media Center for Asia (CEMCA), and the Commonwealth of Learning.

[2] Pituch, K. A., \& Lee, Y. K. (2006). The influence of system characteristics on e-learning use. Computer \& Education, 47(2): 222-244

[3] McFarland, D. J., \& Hamilton, D. (2006). Adding contextual specificity to the technology acceptance model. Computers in Human Behavior, 22(3): 427-447.

[4] Davis, F. D. (1989). Perceived usefulness, perceived ease of use, and user acceptance of information technology. MIS Quarterly, 13(3): 319-340.

[5] Venkatesh, V., \& Davis, F.D. (2000). A Theoretical Extension of the Technology Acceptance Model: Four Longitudinal Field Studies. Management Science, 46(2): 186-204.

[6] Venkatesh, V., Morris, M.G., Davis, G.B., \& Davis, F.D. (2003). User Acceptance of Information Technology: Toward a Unified View. MIS Quarterly, 27(3): 425-478.

[7] Barnett, T., Kellermanns, F., Pearson, A., \& Pearson, R. (2007). Measuring information system usage: Replication and extensions. The Journal of Computer Information Systems, 47(2): 76-85.

[8] Fagan, M., Neill, S., \& Woolridge, B. (2008). Exploring the intention to use computers: An empirical investigation of the role of intrinsic motivation, extrinsic motivation and perceived ease of use. Journal of Computer Information Systems, 48(3): 31-37.

[9] Jones, C. M., McCarthy, R. V., Halawi, L., \& Mujtaba, B. (2010). Utilizing the Technology Acceptance Model to Assess the Employee Adoption of Information Systems Security Measures. Issues in Information Systems, XI(1): 9 - 16.

[10] Venkatesh, V. (2000). Determinants of Perceived Ease of Use: Integrating Control, Intrinsic Motivation, and Emotion into the Technology Acceptance Model. Information Systems Research, 11(4): 342-365. 
[11] Selim, Hassan M. (2006). E-Learning Acceptance Model. Emerging Trends and Challenges in IT Management. Retrieved February 25, 2013 from http://www.irmainternational.org/viewtitle/32713/.

[12] Mahdizadeh, M., Biemans, H., \& Mulder, M. (2008). Determining factors of the use of e-learning environments by university teachers. Computers \& Education, 51(1): $142-154$.

[13] Lee, Y.-H., Hsieh, Y.-C., \& Hsu, C.-N. (2011). Adding innovation diffusion theory to the technology acceptance model: Supporting employees' intentions to use elearning systems. Educational Technology \& Society, 14(4): 124-137.

[14] Ramadiani, Rodziah binti Atan, Mohd. Hasan Selamat, Noraini Che Pa, and Rusli Abdullah. (2013). E-Learning User Interface Acceptance Based on Analysis of User's Style, Usability and User Benefits. Journal of Information Systems, 9(1): 6-12.

[15] King Yee, H.T., Su Luan, W., Mohd Ayub, A.F., \& Mahmud, R. (2009). A review of the literature: Determinants of online learning among students. European Journal of Social Sciences, 8(2): 246 - 252.

[16] Usluel, Y. K., Aşkar, P., \& Baş, T. (2008). A Structural Equation Model for ICT Usage in Higher Education. Educational Technology \& Society, 11(2): 262-273.

[17] Hadebe, X. \& Digada, R. (2010). Factors affecting the use and adoption of eLearning at Higher Education Institutions: Lessons from the University of the Witwatersrand. In J. Sanchez \& K. Zhang (Eds.), Proceedings of E-Learn: World Conference on ELearning in Corporate, Government, Healthcare, and Higher Education 2010 (pp. 484-493). Chesapeake, VA: Association for the Advancement of Computing in Education (AACE). Retrieved September 26, 2015 from http://www.editlib.org/p/ 35591.

[18] Al-alak, B.A., \& Alnawas, I.A.M. (2011). Mea-suring the Acceptance and Adoption of E-Learning by Academic Staff. Knowledge Management \& E-Learning: An International Journal, 3(2): 201 - 221.

[19] De Leeuw, E.D. (2008). Choosing the method of data collection. In Edith D. de Leeuw, Joop J. Hox, and Don A Dillman (Eds.), International handbook of survey methodology (pp. 113-135). New York: Lawrence Erlbaum Associates.

[20] Davis, F. D., Bagozzi, R. P., and Warshaw, P. R. (1989). User Acceptance of Computer Technology: A Comparison of Two Theoretical Models. Management Science, 35(8): 982-1002.

[21] Taylor, S., and Todd, P. A. (1995). Assessing IT Usage: The Role of Prior Experience. MIS Quarterly, 19(2): 561-570.

[22] Hair, Jr., J.F., Black, W.C., Babin, B.J., Anderson, R.E., \& Tatham, R.L. (2006). Multivariate data analysis. $6^{\text {th }}$ edition. New Jersey: Pearson Education, Inc. 